BNWL-2022

UC-20

\title{
Biological Effects of Tritium Releases from Fusion Power Plants
}

\author{
J. A. Strand \\ R. C. Thompson
}

September 1976

Prepared for the Energy Research and Development Administration under Contract E(45-1)-1830 
This report was prepared as an account of work sponsored by the United States Government. Neither the United States nor the Energy Research and Development Administration, nor any of their employees, nor any of their contractors, subcontractors, or their employees, makes any warranty, express or implied, or assumes any legal liability or responsibility for the accuracy, completeness or usefulness of any imformation, apparatus, product or process disclosed, or represents that its use would not infringe privately owned rights.

\author{
PACIFIC NORTHWEST LABORATORY \\ operated by \\ BATTELLE \\ for the
}

ENERGY RESEARCH AND DEVELOPMENT ADMINISTRATION

Under Contract E(45-1)-1830

\author{
Printed in the United States of Ametict \\ Available from \\ National Terhnical Information Service \\ U.S. Department of Commerce \\ 5285 Port Royal Road \\ Springfield, Virginia 22151 \\ Price: Printed Copy 55.00; Microfiche \$2.25
}


BNWL -2022

BIOLOGICAL EFFECTS OF TRITIUM RELEASES FROM FUSION POWER PLANTS

by

J. A. Strand

R. C. Thompson

September 1976

Battelle

Pacific Northwest Laboratories

Richland, Washington 99352 


\section{PREFACE}

Fusion reactor technology has developed far enough to expect laboratory demonstration of practical levels of fusion employing the D-T reaction to occur in the early i980s. Following that demonstration, and depending upon the national priorities for energy from $D-T$ fusion, construction and operation of experimental reactors and demonstration power reactors could occur before the end of this century. Operation of the first conmercial power plants could then follow, starting about 2010 .

Development and adoption of a new power system eventually will require a description of the environmental effects in an environmental statement providing a comparison to the effects of competitive systems. In anticipation of that statement, an environmental analysis (BNWL-2010) has been prepared for the ERDA Division of Magnetic Fusion Energy. That analysis estimates the environmental effects of constructing and operating D-T fusion reactors as an economically competitive source of electricity in the 21 st century.

The analysis has four primary purposes:

1. To describe the general nature of the environmental effects,

2. To determine current ability to estimate the effects,

3. To determine methods for reducing the effects, and

4. To determine research necessary for increasing capability to define and reduce the effects.

Timely identification of needed research and methods for reducing effects will permit the performance of that research and the revision of conceptual fusion power plant designs before preparation of the program environmental statement. This would improve the quality of the environmental statements and could reduce the estimated adverse environmental effects due to fusion power plants.

The environmental analysis (BNWL-2010) concludes that the following assumed characteristics are the best set for the first operating fusion power plants:

- The D-T fusion reaction

- Large quantities of activation products

- Kilogram quantities of tritium in the plant systems

- Massive reactor structures

- Large lithium inventories

- Large inventories of 1 iquid metals and salts
- Standard electricity generation

- Standard radioactive waste systems

- Large magnetic fields

- A self-contained fuel cycle

- Rural siting

Using these characteristics a reference reactor was analyzed to determine the environmental effects by using available concepts of plant subsystems designs that control interactions with the environment or by assumption that best current technology would be used in subsystems design.

Because this analysis does not take into account advances in both fusion and waste control technology during the next thirty years, the estimated effects probably are significantly higher than the actual effects will be for the first fusion power plants. The estimated environmental effects should be interpreted only as being the probable upper 1 imit for the actual effects. 
Preparation of the fusion power plant environmental analysis required development and use of specially developed data and analysis methods not used in the preparation of current environmental statements for fossil and fission power plants. These data and analysis requirements are documented in a series of reference topical reports to make this information publicly available and to assure understanding of the basis for the conclusions made in the environmental analysis. These reference topical reports summarize the state-of-the-art as applicable to preparation of environmental statements for fusion power plants. They present the data and analytical techniques used in the environmental analysis to estimate the interactions with the environment and the resultant environmental effects. This information then was analyzed for adequacy and the need was determined for additional research to assure satisfactory ability to prepare environmental statements for the fusion development program and experimental facilities in the early 1980s. Estimated environmental effects are presented in these reference documents only as necessary to illustrate use of the data and analytical techniques.

This report is one of those reference documents for the environmental analysis. The other documents in this series contain more details of the power plant concepts and the probable environmental effects of fusion power plants with the assumed characteristics listed above. These documents are available through the National Technical Information Service:

An Environmental Analysis of Fusion Power to Determine Related R\&D Needs, BNWL -2010

Review of Fusion Research Program: Historical Summary and Program Projections, BNWL-2011

Fuel Procurement for First Generation Fusion Power Plants, BNWL-2012

Current Fusion Power Plant Design Concepts, BNWL-2013

Reference Commerical Fusion Power Plants, BNWL-2014

Siting Commercial Fusion Power Plants, BNWL-2015

Materials Availability for Fusion Power Plant Construction. BNWL-2016

Projected Thermodynamic Efficiencies of Fusion Power Plants, BNWL-2017

Tritium Source Terms for Fusion Power Plants, BNWL-2018

Management of Nontritium Radioactive Wastes from Fusion Power Plants, BNwL-2019

Methodology for Estimating Radiation Doses Due to Tritium and Radiocarbon Releases, BNWL-2020

Magnetic Field Considerations in Fusion Power Plant Environs, BNWL-2021

Biological Effects of Tritium Releases from Fusion Power Plants, BNWL-2022

Biological Effects of Activation Products and Other Chemicals Released from Fusion Power Plants, BNWL-2023

Safety Review of Conceptual Fusion Power Plants, BNWL-2024

An Investigation of the Transportation Requirements of Fusion Power Plants, BNWL-2025

Considerations of the Social Impact of Fusion Power, BNWL-2026

Environmental Impacts of Nonfusion Power Systems, BNWL-2027

Environmental Cost/Benefit Analysis for Fusion Power Plants, BNWL-2028

Biomagnetic Effects: A Consideration in Fusion Reactor Development, BNWL-1973

An Analysis of Tritium Releases to the Atmosphere by a CTR, BNWL-1938 


\section{CONTENTS}

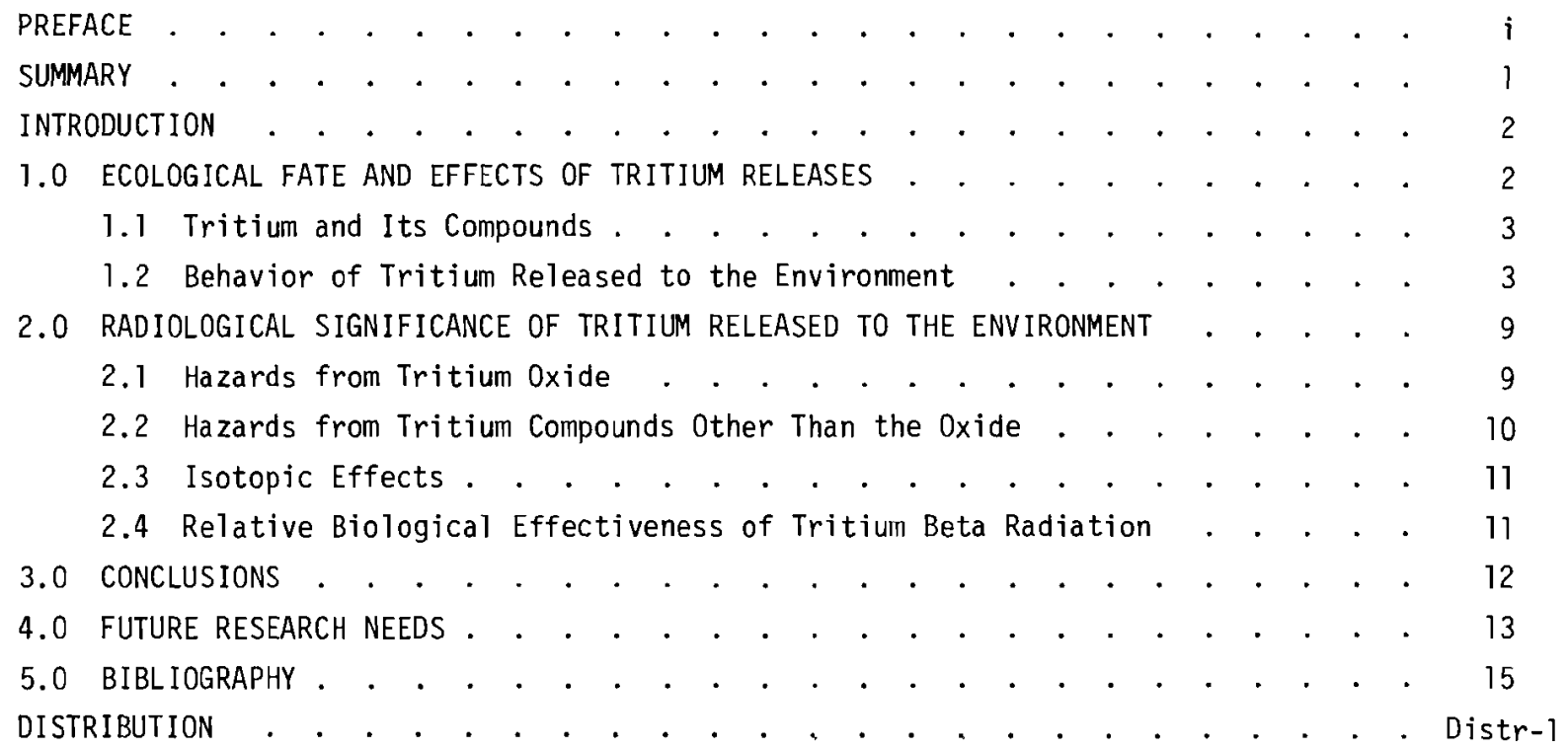


Tritium released as tritium oxide will behave like ordinary water throughout the hydrosphere, and is readily metabolized by all living organisms. Although most biochemical reactions discriminate against the incorporation of tritium, the possibility of some concentration should not be overlooked. A fraction of tritium in the body as tritiated water becomes organically bound; that is, exchanges with hydrogen bound in organic molecules. However, organic binding is not expected to result in significant bioaccumulation of tritium from tritiated water, because water is approximately as hydrogen rich ( $21 \%$ by weight) as any compound of the biological organism ( $10 \%$ by weight). Processes that allow accumulation and incorporation of tritium assist in its elimination. Tritium, which is organically bound, demonstrates a longer half-time in the body, but it would appear to constitute a small fraction of the total tritium label.

Tritium released as HT is of much less concern than HTO because it is not readily incorporated into living organisms. The dose rate for HT is only $0.5 \%$ of the dose rate for HTO.

Extensive studies over the past 30 years have failed to produce tritium effects data significantly different from those which might have been predicted from a general knowledge of the effects of ionizing radiation. Although recent biological effects studies suggest uncertainty as to the appropriate RBE for tritium, this would likely be no greater than three or four. However, if fusion reactors hold tritium releases within ICRP standards, no significant impact to the environment from those releases are expected.

Ample information is available to permit reasonable estimates of the dose rates and biological effects for tritium. However, some uncertainties still exist and should be eliminated by continuing research.

Future research needs include confirmation of the current estimates of concentration factors and turnover rates resulting from both acute and chronic exposures. Temporal and spatial variations must be followed and trophic relationships need additional study. Relatively few studies have been conducted on assessment of potential genetic effects, particularly under conditions of chronic exposure. More information on radiation effects on individuals, populations, and communities needs to be developed. Longer term or chronic studies should consider factors such as rates of growth, morphological abnormalities, onset of maturity, and reproductive capacity. Chromosomal studies under both laboratory and field conditions should be extended, and the somatic and genetic consequences of such changes on populations, communities, and ecosystems should be evaluated. In particular, deficiencies in our knowledge lie in our lack of understanding of the basic relationships between very low-level, low-dose-rate, radiation exposure, and health effects. Properly designed large scale, multi-generation, tritium exposure studies in experimental animals could add to our present knowlege of these basic relationships. Other research needs include better definition of source terms. The oxidation of released tritium and the degree to which it remains as elemental tritium should be determined.

All of this research should be considered as necessary to assure preparation of adequate environmental statements. Primary emphasis should be placed on definition of source terms and the oxidation rate of tritium in the environment. Secondary emphasis should be placed on tritium biological effects. 


\section{INTRODUCTION}

Releases of tritium will cause radiation doses to all forms of life. The quality of estimates of effects of tritium radiation doses depends on the quality of current knowledge concerning the effects of tritium on life forms. This section describes the current status of knowledge of the biological effects of tritium. First, the general ecological fate of tritium in the environment is discussed. Then, the general effects of tritium are described.

\subsection{ECOLOGICAL FATE AND EFFECTS OF TRITIUM RELEASES}

Tritium is a radioactive isotope of hydrogen and is produced under natural conditions within the atmosphere by interaction of cosmic energy with nitrogen and oxygen. Nir, et al. (1964) concluded that the natural production rate resulted in a total equilibrium inventory in the biosphere of approximately 69 megacuries of tritium. Jacobs (1968) estimated the natural annual production to be 4-8 megacuries. Most of this naturally-produced tritium ( $290 \%$ ) is in the hydrosphere consisting of the oceans and other water bodies.

Tritium was also released to the biosphere during the period of atmospheric testing of nuclear weapons and devices. Eriksson (1965) estimated that approximately 1700 megacuries of tritium were produced in tests through early 1962. This amounted to nearly 25 times the steady-state inventory from natural sources. A 3 year half-time of tritium in the stratosphere was estimated for such weapons-produced tritium; however, more recent findings suggest the residence half-time is on the order of ten days (Koranda, 1971).

The recent trend of using nuclear fission as an energy source for electrical power generation has also served to release increasing amounts of tritium to the environment. Rhinehammer and Lamberger (1973) have indicated that a 500 MWe boiling water reactor (BWR) (zirconium clad) will release 0.5 to 5 curies per year of gaseous tritium and, no greater than 25 curies per year in liquid effluents. A 500 MWe pressurized water reactor (PWR) (zirconium clad) will release <100 curies per year in liquid effluents. Rhinehammer and Lamberger (1973) also indicated that a 370 MWe pressurized water reactor (PWR) (stainless steel clad) will release $<100$ curies per year gaseous tritium but may release 22700 curies per year of tritium in 1 iquid effluents. Based on the projected nuclear economy for the U.S. and the free world, the rate of production of fission-produced tritium will exceed the rate of natural production by 1990 (Jacobs, 1968).

Tritium breeding in D-T burning fusion reactors is expected to occur at a high rate, with an estimated doubling time of months. Consequently, the inventories of tritium will be greater than for present fission designs. As in either the BWR or PWR designs, some tritium is anticipated to escape the plant in both liquid and gaseous effluents. 
With this projected increase in the release of tritium resulting from fusion reactor operation, it is necessary to know how readily tritium is metabolized by biological organisms, and at what levels of radiation dose adverse effects may be expected. The existing information is summarized in the following sections.

\subsection{Tritium and Its Compounds}

The biological effects of tritium may be considered in terms of potential hazards from elemental tritium as the gas HT, from the oxide HTO, and from tritium compounds other than oxide.

Tritium Gas (HT). HT oxidizes to HTO when it burns or explodes; or without combustion, by auto-oxidation, where the energy required to drive each oxidation reaction is provided by beta particles from other tritium atoms. HT may also oxidize in air at normal temperatures in the presence of suitable catalytic surfaces such as dust or equipment walls. However, the nature of such reactions is poorly understood and oxidation rates are not known.

Tritium Oxide (HTO). Tritium combines with oxygen to form tritium oxide or water which is the compound of principal hazard concern. As all water contains tritium, a clear distinction between tritiated and nontritiated (tritium-free) water is not possible. Tritiated water is usually defined as any light or heavy water that contains more than $30 \mu \mathrm{Ci}$ of tritium per liter ( $210^{7}$ tritium units, a tritium unit is one atom of tritium per $10^{18}$ atoms of hydrogen). When tritiated water is released to the atmosphere, isotopic exchange processes result in dilution of tritium with atmospheric humidity in the form of HTO. Tritiated water vapor is generally referred to as HTO, although it may consist of both HTO and DTO in any proportion.

Other Tritium Compounds. Tritium may become a constituent of any compound containing hydrogen. Most such compounds, if burned, will oxidize to HTO and other combustion products.

\subsection{Behavior of Tritium Released to the Environment}

Elemental Tritium (HT). Hydrogen gas (HT) is not metabolized by higher organisms and is not solubilized to any significant degree in body fluids or tissues. More than 99 percent of inhaled tritium is rapidly exhaled by rats (Smith, et a1., 1953; Pinson and Langham, 1957), and even a lower retention efficiency is reported for humans (Pinson and Langham, 1957). Absorption of tritium gas through the integument is shown to be insignificant (DeLong, et al., 1954). Conversion of tritium to the more metabolically active oxide (HTO) is considered to be slow, even in the presence of suitable catalytic surfaces (Eakins and Hutchinson, 1973).

Tritium Oxide (HTO). Tritium oxide, the compound of principal hazard concern, is water, which is the most studied and best understood of al1 compounds.

Terrestrial Considerations. Jacobs (1968) indicated that, in general, tritiated water is expected to behave as ordinary water in the ground, except for a slight difference in vapor pressure. However, water associated with minerals may have various degrees of mobility, depending upon the nature of the association. In a water saturated formation, the greater fraction of water exists as ordinary water that occupies the interparticle spaces. This water 
is considered freely mobile and its velocity of movement depends upon pore size. Loosely-bound water of hydration was found on the mineral surface (Joergensen and Rosenquist, 1963). This water was considered to be in equilibrium with the environment after a short time and was removable at temperatures below $750^{\circ} \mathrm{F}\left(400^{\circ} \mathrm{C}\right)$. A second phase of absorbed water required a much longer time to attain an equilibrium and was vaporized at 392 to $932^{\circ} \mathrm{F}\left(200\right.$ to $\left.500^{\circ} \mathrm{C}\right)$. Finally, a third phase (structural hydroxyl group) required either a very long time or hydrothermal alteration for exchange and was only removed at temperatures ranging between 932 to $2012^{\circ} \mathrm{F}\left(500\right.$ to $\left.1100^{\circ} \mathrm{C}\right)$.

Jacobs (1968) furthermore reported that the impact of all such adsorbed phases on tritium behavior in the ground was dependent on two factors: 1) the relative amounts of these phases compared with free water in the pores, and 2) conditions under which adsorption and desorption occurred. The relative amounts of each adsorbed phase increased as the moisture content decreased. As such, tritiated water is expected to move more slowly through a very dry soil than through a moist soil. If tritiated water is deposited under conditions of high temperature, i.e., nuclear denotation, exchange with the structural hydroxyl groups will occur.

Koranda (1965) found the mineral bound tritium of soil at the Pacific Proving Grounds to be very high. The concentration in free water in the soil was 60 tritium units; the concentration in bound water was $3.7 \times 10^{5}$ tritium units. The soil consisted of almost entirely $\mathrm{CaCO}_{3}$ and $\mathrm{Ca}(\mathrm{OH})_{2}$.

In a saturated fraction, nearly all the tritiated water will exist in the interparticle pores, and its movement wi11 depend upon the dispersive characteristics of the formation. Nakayama and Jackson (1963) reported that the diffusion coefficient for tritiated water in soil was nearly constant for a range of volumetric water contents between 10 and 40 percent. Below 10 percent, the diffusion coefficient increased rapidly with a maximum at 4 percent water content, suggesting gaseous diffusion of water vapor through the larger of interparticle pores. Below 4 percent water content, the diffusion coefficient decreased rapidiy suggesting the influence of adsorbed phases.

Gorham and Hofstetter (1971) studied the penetration of tritium of atmospheric origin in bog peats and lake sediments of the Red Lake wetlands in northern Minnesota. They found that tritium in surface bog peats exhibited nearly the same concentration as in atmospheric precipitation, which was still appreciably enriched from nuclear weapon testing. Past input pulses from recent testing were not preserved in the peat profile. The pattern of subsurface decline suggested that most of the modern precipitation rich in tritium was removed rapidly by evapotranspiration and by lateral runoff within the surface $1.5 \mathrm{~m}$ of the $3.5 \mathrm{~m}$ thickness of little-decomposed peat at the crest of the raised bog. However, some tritium of weapons origin did penetrate down to the discontinuity between surface material and the well-decomposed bog peat, presumably by molecular diffusion. 
In profundal lake sediments, Gorham and Hoffstetter (1970) found the influence of enriched precipitation from the early 1960s to be largely transitory and of only major significance in sediment depths of less than 1 meter. Again, some penetration below this depth occurred and was likely attributable to molecular diffusion.

Jorden, et al. (1971) studied the movement of tritium as HTO through the soils of a montane tropical rain forest in eastern Puerto Rico and determined that HTO moved downward through the soil as a function of the amount of rain water entering the soil above the pulse. Concomitant to downward penetration, the peak was found to broaden and flatten due to diffusion. The pulse became immobile if the upper soil dried out to the extent that rain water did not penetrate to the depth of the pulse peak. Concentrations of tritium in vegetation equaled concentrations in soil water at the depth at which the plants were taking up water. Loss of tritium from the system occurred by evapotranspiration and deep drainage.

Cline (1953) investigated the uptake of HTO by the red kidney bean, Phaseolus vulgaris, and determined that uptake occurred rapidly over the first few hours, but equilibrium between plant water and that of the nutrient medium was not attained over the 72-hour duration of exposure. The rate and degree of incorporation were correlated with metabolic activity.

Raney and Vaadi 11965) conducted similar experiments on the movement and distribution of HTO in tissue water of shoots of sunflower, Helianthus annus, and tobacco, Nicotina rustica. This distribution of tritium in plant organs with roots in tritiated water was followed as a function of time. During a 12-hour light period, concentrations of tritium in the stem tissue and the petioles of mature leaves approached equilibrium with the concentration of tritium in the nutrient solution. The approach to equilibrium was much slower in the terminal nodes and internodes that were still elongating and in leaf tissue still expanding. The tritium concentration in the leaves of intact plants growing in tritiated water did not reach an equilibrium with the external medium over a protracted period. Although the veins equilibrated in a manner similar to that of the stem, the interveinal tissue did not reach equilibrium with the major veins, the stem, or the nutrient solution. It was demonstrated that the lack of equilibrium in interveinal tissue was attributed to exchange of tritium between the leaf and the atmosphere by transpiration.

Thompson (1952, 1953) studied metabolic turnover rates of tritium in higher animals. In mice, he demonstrated the biological half-life of tissue-free body water to be approximately 1.1 days. The loss curve of tritium from the tissue-bound fraction was resolvable into coniponents of 9 and 90-day half-life, which were shown to be of comparable tritium-binding capacity. The biological half-life of tissue-free body water in the rat was found to be 3.3 days. All organs and tissues sampled, with the exception of blood, demonstrated components which eliminate tissuebound tritium with a biological half-life of 80 days or longer. Evidence was presented which suggested that these longer lived components represented a significant proportion of the total metabolically replaceable hydrogen. 
Thompson and Ballou (1954) separated protein and lipid fractions from various tissues of rats sacrificed 4 and 8 months after administration of tritium oxide. The concentration of bound tritium in these fractions was determined and biological half-life calculated. Collagen fractions demonstrated half-lives of 300 days or longer, and lipid fractions were obtained with half-lives as long as 300 days. The highest concentration of tissue-bound tritium, 4 months after administration, was found in brain lipids.

In other studies, Thompson and Ballou (1954) exposed mature female rats to constant levels of tritium oxide, mated them after 6 weeks' exposure, maintained the exposure conditions over intrauterine development and nursing of the progeny, and then maintained the progeny on an identical exposure level for an additional 6 months. The progeny were then removed from the contaminated environment and sacrificed at intervals, and selected tissues were analyzed to determine the tritium concentration of their tissue-free water and tissue-bound fractions. In those animals sacrificed immediately after exposure, most tissues sampled yielded tissue-bound values of 20 to 30 percent of the concentration of the tissue-free water during exposure. The authors interpreted this to mean that 20 to 30 percent of the organically bound hydrogen (both freely exchangeable and firmly bound) was derived from the tissue-free water.

In more recent studies, Evans (1969) found the same tritium concentration in the tissue-bound fraction as in the tissue-free water fraction from tissues of 52 deer killed on the Savannah River Nuclear Site. His interpretation was that sustained exposure to tritiated body water would result at equilibrium in labeling of all organic molecules equal to that of the tissuefree water on a per gram hydrogen basis. He concluded that the body burden due to continuous low-level exposure to tritiated water would be 1.4 or 1.5 times greater than that predicted by current models. The deer studied were assumed to have received tritium as tritiated organic molecules in their forage.

Koranda, et a1. (1969) reported similar results based on analysis of tritium in the tissuefree water and tissue-bound residues of 95 kangaroo rats from the elevated tritium environment of the Sedan Crater at the Nevada Test Site. Tritium activity in the lyophilized residues of 6 organs based on per gram hydrogen averaged 1.5 times as high as that measured in the tissuefree waters. After extrapolating their data to man in a situation of continuous low-level exposure they concluded that the body burden and concomitant dose would be approximately 1.8 times that predicted by current models. The kangaroo rat subsists on dry forage without any free water. The exposed animals were assumed to have derived most or all of their tritium from ingestion of tritiated forage, and that tritium in their tissue-free water was derived mainly from catabolism of the tritiated molecules.

Moghissi, et a1. (1971) and Barth, et al. (1972) investigated tritium kinetics in goats and reported a residence half-life of approximately 4 days in lactating, and approximately 8 days in nonlactating animals. In related studies of tritium turnover in the blood of cows, Potter, et a1. (1972) reported values of 12.5 and 65 days for short and long components, respectively. Moghissi, et al. (1971, 1972) in studies of the human demonstrated a two component exponential loss rate with a half-life of 21 to 33 days for the short component and 280 to 550 days for the long component. 
Aquatic Considerations. Isotopic discrimination against incorporation of tritium into plants is well documented. Rosenthal (1971) cultured the alga, Chlamydomonas reinhardti, in tritiated water and determined a marked isotopic discrimination against incorporation of tritium into organic molecules. Tritium in the cell fluid, however, tended to equilibrate with that in the external environment. Some published results also suggest discrimination in favor of retention once tritium is incorporated.

Foster (1955) investigated tritium oxide absorption and retention in the body water of salmon fry, Oncorhynchus tshawytscha, mayfly nymphs, Callibaetis spp., and snails, Radex japonica, maintained in a tritiated environment for 24 hours. After removal to an uncontaminated environment, the organisms were sampled at intervals ranging from 1 minute to 8 hours. Half-life values of approximately 10 minutes for snails, 20 minutes for mayfly nymphs, and 24 minutes for the salmon fry were calculated.

Stewart, et a1. (1971) studied tritium accumulation in two species of snails, Lymnaea reflexa, and Hel isoma trivolvis, and the leopard frog tadpole, Rana pipiens. The tissue-free water of the snails approached equilibrium with the environmental HTO in approximately 6 hours. The tissue-free water tritium in tadpoles exceeded environmental levels in 3 hours. The final equilibrium level was 1.11 times greater than the environmental level. Tissue-bound tritium attained equilibrium in the snails in approximately 5 days but was not observed to reach equilibrium in tadpoles in 10 days when the experiment was terminated.

Strand, et al. (1971) studied the accumulation and retention of tritium in embryonic and larval rainbow trout, Salmo gairdneri. For embryos exposed to tritiated water, a rapid uptake over the first 1 to 2 days was demonstrated, followed during the ensuing 27 to 28 days of exposure by maintenance of essentially equilibrium levels. The tissue-bound tritium accounted for approximately 20 percent of the total label in each egg, a level not exceeded as measured over the duration of exposure. Both tissue-free water and tissue-bound fractions, after transfer to uncontaminated water, eluted rapidly with estimated half-times of $\sim 1.0$ and 02.0 hours respectively. A slower component of the tissue-free water fraction persisted for 017 days, as determined in hatched fry. The slow component of the tissue-bound fraction, for comparison, persisted at approximately 0.5 percent of the initial bound equilibrium level at 17 days.

The tissue-bound tritium of water fleas, Daphnia galeata; fairy shrimp, Eubranchipus vernalis; snails, Lymnaea reflexa and Helisoma trivolvis; and northern chorus frog tadpole, Pseudacris triseriata; was found by Rosenthal and Stewart (1971) to be derived chiefly from the consumption of tritiated forage. However, tissue-free water tritium was derived mainly from the surrounding waters. They also determined that approximately $1 / 3$ of the intracellular-bound tritium in snails was not exchangeable.

Harrison and Koranda (1971) studied the tritiation of aquatic animals in an experimental freshwater pool. They found that in the tissue-free water of clams, Anodonta nuttalliana; crayfish, Astacus spp.; goldfish, Carassius auratus; cattail, Typha angustifolia; and filamentous algae, Pithophora spp., tritium increased to 95 percent of the level in the pool water and remained at 
that level for the duration of the experiment. Tissue-bound tritium had a higher concentration in plants than in animals, the organically-bound tritium was highest in the visceral organs and lowest in calcified tissues. In the viscera, tissue-bound tritium increased to approximately 60 percent of the concentration of tissue-free water tritium. In muscle tissue it increased to a maximum of 30 percent of the concentration in tissue water over a period of 90 days.

Strand, et al. (1975) conducted similar studies in a simulated aquatic ecosystem containing carp, Cyprinus carpio; clam, Anodonta californiensis; crayfish, Pacifastacus trowbridgii; and snail, Lymnaea spp. Tritium as tritiated water was introduced for 8 months continuously in the replacement water at a concentration of $1 \mu \mathrm{Ci}$ per liter. The system was maintained on uncontaminated replacement waters for an additional 8 months to determine the rate of el imination from the ecosystem.

After the first day, tissue-free-water tritium in all biota approached an equilibrium with pond water. Final concentration factors of $0.89,0.87,0.82,0.92,0.77$, and 0.88 were calculated for carp, clam, crayfish, snail, periphyton, and pondweed. Tissue-bound tritium initially increased rapidly in all biota sampled but slowed with time. Equilibrium conditions were not reached. Final concentration factors for carp, clam, crayfish, snail, periphyton, and pondweed were calculated to be $0.49,0.10,0.53,0.54,0.15$, and 0.62 .

Loss of tritium from pond waters occurred exponentially with time with less than 10 percent of the final equilibrium concentration remaining after the first month. Rate of loss of tritium from both animal and plant species was also rapid, with animal forms generally el iminating their respective tritium burdens more rapidly than plant forms.

Van Hook and Deal (1973) studied the transfer of HTO from water to watercress to crickets and determined that adult crickets reached tritium concentrations less than water equilibrium levels, 0.19 . They concluded that other factors such as food habits and developmental stage were as important as simple diffusion from environmental concentrations in accounting for the degree of tritiation observed.

Tritium Compounds Other Than Tritium 0xide. In a tritiated environment, a significant proportion of an organism's tritium intake may be in the form of tritiated organic compounds in food materials. Although most such organically labeled tritium entering the organism will be converted to the oxide form by either oxidation or exchange reactions, there is also opportunity for direct incorporation into body tissues of certain tritiated compounds. Still other tritiated compounds may be formed by either exchange or synthesis. In essence, all compounds containing hydrogen may be expected to incorporate tritium. 


\subsection{RADIOLOGICAL SIGNIFICANCE OF TRITIUM RELEASED TO THE ENV IRONMENT}

\subsection{Hazards from Tritium Oxide}

Because elemental tritium as HT gas is not readily metabolized by biological organisms, nor rapidly converted to the more metabolically active tritium oxide, it is not generally considered to present a significant immediate radiological hazard to the environment. Accordingly, the ICRP recommended maximum permissible concentration for elemental tritium in air in contact with the general public is $4 \times 10^{-5} \mu \mathrm{Ci} / \mathrm{cm}^{3}$, a level 200 times higher than the maximum permissible concentration for tritium oxide in air (ICRP, 1959).

Tritium as tritium oxide must be considered more hazardous because it is metabolized like ordinary water and is readily distributed throughout all biological tissues. However, the concomitant radiological hazard is predictable. Tritium oxide, whether inhaled, ingested, or absorbed through the integument, may be expected to rapidly equilibrate with free tissue water of the living organism. Because free tissue water is uniformly distributed throughout the living organism, the resulting radiation dose is uniformly administered to the total organism. However, some tissues such as bone, with a low water content, receive a relatively lower dose. Incorporation of tritium from free tissue water into organic compounds of the living organism tends to increase total radiation dose. However, the increase may not be expected to exceed 50 percent, a maximum established by the ratio of tissue-bound hydrogen to tissue-free water hydrogen.

For nonchronic exposure, the evaluation of radiation doses is somewhat more complex since equilibrium levels will not be attained. However, the rates of turnover of body water and of the various organic components of the body have been studied extensively. The available information can be used to obtain good estimates of the whole-body radiation exposure resulting from an acute intake of tritium oxide (Snyder, et al., 1968; Croach, 1973; Balonov, et al., 1974).

What is not so easily determined is the radiation dose to very limited regions of the body, whose dimensions may be small relative to the uniformity of hydrogen distribution within tissues or compounds. This is the problem encountered with exposure from specific tritiumlabeled compounds, which will be discussed in the next section.

While the estimation of radiation dose from tritium oxide in body water is probably on firmer grounds than dose estimation for any other internally deposited radionuclide, the translation of this dose estimate to an estimate of biological effect is subject to the uncertainties connected with any prediction of biological effect from very low radiation doses. Recently reported studies attest to the damaging effects of tritium beta radiation at low exposure levels. Laskey, et al., (1973) observed a significantly reduced brain weight in neonatal rats born to rats that had received a continuous lifetime exposure to tritium oxide with a cumulative wholebody dose of less than 5 rads. Dobson and Cooper (1974) observed a significant reduction in surviving primary oocytes of 14-day-old mice exposed to tritium oxide from conception with a 
cumulative whole-body dose of less than 1 rad. Strand et a1. (1972, 1975) determined that the primary immune response of rainbow trout, Salmo gairdneri, was significantly impaired following exposure to tritiated water at levels as $10 \mathrm{w}$ as $1.0 \mu \mathrm{Ci} / \mathrm{m \ell}(4.0 \mathrm{rad})$, as administered over 20 days of embryogenesis. While such low-level effects are not unique to irradiation from tritium, the relatively large quantities of tritium that may be released and its ubiquitous distribution in the environment and in man may result in the most likely possibility for increasing the unavoidable chronic exposure from natural background.

In general, the research on both somatic and genetic effects attributed to tritium has failed to produce results that are significantly different than those which would have been predicted from a general knowledge of ionizing radiation. It may then be assumed that current maximum permissible concentrations, for tritium oxide, $2 \times 10^{-6} \mu \mathrm{Ci} / \mathrm{cm}^{3}$ in air, $3 \times 10^{-2} \mu \mathrm{Ci} / \mathrm{cm}^{3}$ in water (ICRP, 1959), are sufficiently conservative to provide protection for the most sensitive components of the environment.

\subsection{Hazards from Tritium Compounds Other Than the Oxide}

In a uniformly tritiated environment about half the tritium intake would be in the form of tritiated organic compounds in food. Most of this organically bound tritium will be converted within the organism to tritium oxide, by oxidation or exchange, but some tritiated organic compounds will be incorporated directly into body tissues. Other tritiated organic compounds will be formed within the body by exchange or synthetic processes. By these two routes, all hydrogen-containing compounds in the body will incorporate tritium. This organically bound tritium will add perhaps 50 percent to the whole-body dose from body water tritium. Whether it might have some special effect because of its molecularly incorporated state has been the subject of much concern and investigation.

Two possibilities exist for enhanced effect: 1) a transmutation effect due to conversion of the disintegrating hydrogen atom to a helium atom, and 2) an enhanced radiation effect due to origin of the beta ray within the molecule. Such effects might be particularly critical for tritium incorporated in DNA or other vital molecules within the cell nucleus.

This problem has been studied and reviewed (Feinendegen, 1967; Feinendegen and Bond, 1973). Although a somewhat controversial subject, there now appears to be agreement on the following conclusions (Feinendegen and Bond, 1973): "The effects of intracellular tritium are overwhelmingly due to beta irradiation of the nucleus. Transmutation effects do not produce a measurably increased effect under most conditions and are detectable only, if at all, under highly specialized laboratory conditions. The origin of tritium beta tracks in, or their close juxtaposition to, the DNA molecule does not appear to enhance the degree of somatic effect." This latter conclusion appears reasonable since, "Every part of the cell nucleus 1 ies within 
one tritium beta range of some part of a chromatid, and the nucleus contains no sizeable contiguous 'insensitive' volume of a radius exceeding the effective range of tritium beta rays." Studies of the induction of gene mutations in mice also indicate the absence of any substantial transmutation effect (Cumming, et al., 1974).

Acute exposures might present special problems. Concern has been expressed for the case in which a developing female fetus is exposed to elevated body water levels during the period of oocyte formation; tritium incorporated in these germ cells would be retained until ovulation and this might constitute a special genetic hazard (Radford, 1968). Osborne (1972), however, has estimated that in such a circumstance, less than 0.2 percent of the initial dose rate to the nucleus originates from tritium incorporated in DNA, and that it would be 30 years before the initial dose from body water was equaled by the cumulative dose from DNA-incorporated tritium.

It would thus appear quite certain that tritium incorporated into organic compounds poses no substantially increased hazard beyond that accounted for by its contribution to whole-body dose.

\subsection{Isotopic Effect}

Because the tritium atom is three times as heavy as the nomal hydrogen atom of mass one, much larger isotope effects are observed than those normally encountered with other elements. This subject was reviewed by Weston (1973) who concluded that, "it is apparent that large kinetic isotope effects are often found for tritium-labeled compounds. In tracer experiments utilizing tritium, observed rate constants could easily differ by an order of magnitude from those for the analogous unlabeled compound. If tritium from a source of HTO at constant specific activity is incorporated into a biological system by irreversible chemical reactions, it will be discriminated against; and the tritium level in the biological system will remain lower than that of the source. Conversely, kinetic isotope effects in the backexchange to remove tritium after incorporation will favor retention of tritium in the biological system." Although rather large isotope effects occur in individual chemical reactions, the overall effects in biological organisms seem relatively small, as discussed by Shtukkenberg, (1968). Thompson and Ballou (1954) made comparisons of tritium and deuterium in rats as did Glasscock and Duncombe (1954). The effects were small as they were in a study of algae (Crespi, et al., 1972). It therefore seems reasonable to assume that tritium will behave like ordinary hydrogen, and that the error introduced by such an assumption will overestimate the effects of tritium.

\subsection{Relative Biological Effectiveness of Tritium Beta Radiation}

Tritium is a pure beta-emitter of very weak energy - $18.6 \mathrm{keV}$ maximum. The linear energy transfer (LET) of such weak betas is higher than that of more energetic beta, $X$-, or gamma radiation, and much experimental effort has been devoted to determining whether this higher LET is 
reflected in an increased RBE. Earlier studies were reviewed by Vennart (1968), who concluded "that a value of CF different from unity of either tritium or other B-emitters is hardly justified." The International Commission on Radiological Protection (ICRP) in its 1959 report on Permissible Dose for Internal Radiation used an RBE (or QF) value of 1.7 for tritium; however, this value was reduced by ICRP to unity in 1969, a value concurred in by the National Council on Radiation Protection and Measurements (NCRP, 1971).

More recently, there has been further evidence presented to justify a value higher than unity (Johnson, 1973; Moskalev, et a1., 1973). Of particular interest are studies of Dobson, et al., (1974, 1975) on the survival of female germ cells in young mice exposed to a continuously maintained level of tritium oxide in body water. These studies seem to indicate an increasing RBE with protraction of exposure, with the suggestion of a limiting RBE value of approximately 4 at very low doses. Such variation of RBE with dose is in accord with microdosimetry theory (Kellerer and Rossi, 1971; Ellett and Braby, 1972), and is supported by bean root and mammalian cell culture studies of Hall, et al. (1967). It is important to note, however, that an increasing RBE at very low doses for the relatively high-LET beta radiation from tritium, is (on theoretical grounds, at least) more likely due to a decreased biological effectiveness of the reference, low-LET radiation, than to an absolute increase in tritium effectiveness. In any event, there would seem to be no indication of an RBE greater than 4 .

With specific regard to the RBE for genetic effects, the induction of mutations by tritium in mice has been recently studied at 0ak Ridge National Laboratory (Cumming, et al., 1974). The report of these studies presents the following conclusion: "Thus, if absorbed dose to the testis is accepted as meaningful for purposes of comparison with gamma or $x$-rays, the ... point estimate of relative biological effectiveness (RBE) for postspermatogonial germ-cell stages is close to 1 , with fairly wide confidence intervals. The point estimate of RBE for spermatogonia is slightly above 2, with confidence intervals which include 1 , and there remains the suggestion that the distribution of mutants among the seven loci may differ from that produced by gamma rays."

\subsection{CONCLUSIONS}

In summary, tritium released as tritium oxide is a much more significant potential hazard to the environment than is elemental tritium. It may be expected to behave like ordinary water throughout the hydrosphere, and is readily metabolized by both terrestrial and aquatic organisms.

Al though most biochemical reactions discriminate against the incorporation of tritium in favor of protium, the possibility of some concentration should not be overlooked. Available information indicates that the isotopic effects of tritium in most exchange reactions are negligible. Data from studies of both acute and chronic exposure conditions generally support the hypothesis that no significant concentration occurs above environmental concentrations in water or forage at any level of the food chain, although data on complex terrestrial and aquatic food chains or 
food webs are not yet available. Moreover, the current data suggest that in most ecosystems, tritium concentration tends to become more dilute at levels of greater organization within the food chain or food web leading to man.

A fraction of tritium accumulated as tritiated water becomes organically bound; that is, exchanges with hydrogen bound in organic molecules. The rate and extent of incorporation are dependent upon metabolic activity of the organism. On this basis, the highest concentration of organically-bound tritium would be expected in tissues and population segments which are in formative or growth stages at the time of exposure. Furthermore, as exposure duration increases from acute to chronic situations, tritium concentrations are shown to approach equilibrium levels with a single tritium-to-hydrogen ratio common to all parts of the hydrogen pool. Organic binding would not be expected to result in significant bioaccumulation of tritium from tritiated water, because water is approximately as hydrogen rich ( $211 \%$ by weight) as any compound of the biological organism ( $210 \%$ by weight). However, the exposure pathway may influence the extent of organic binding. Recent evidence indicates that enhanced binding may result from ingestion of tritiated foodstuffs.

Tritium loss, both from tissue-free water and the tissue-bound fraction, depends upon metabolic activity. Processes that allow accumulation and incorporation of tritium also assist its elimination. Tritium which is organically bound demonstrates a longer half-time, but it would appear to constitute a small fraction of the total tritium label.

Extensive studies over the past 30 years have demonstrated no unique behavior for tritium in the biosphere that would not have been predicted with consideration for the principal compound. Moreover, experimentation failed to produce effects data significantly different from those which might have been predicted from a general knowledge of the effects of ionizing radiation.

The radiation exposure of all living organisms by environmentally dispersed tritium, in whatever form, is essentially a whole body exposure. Uncertainties in the individual parameters, involved in converting measured intake to estimated dose equivalent are probably no larger than a factor of three or four.

If fusion reactors hold tritium releases with ICRP standards, no significant adverse impact to the environment from those releases are expected.

\subsection{FUTURE RESEARCH NEEDS}

In general, ample information is available for reasonable estimates of the biological effects and radiation doses due to tritium. However, because some uncertainties exist, additional research appears necessary.

From the literature review, it is apparent that relatively few studies have been conducted on the cycling of tritium through either the abiotic or biotic compartments of natural ecosystems. Furthermore, there exists little information on the behavior of this radionuclide in temperate climates paramount to assessment and prediction of the potential environmental effects and dose commitment to natural populations. For both acute and chronic releases of tritium, current estimates of concentration factors and turnover rates in the various compartments need confirmation. To more fully understand the relationship between the concentrations of tritium in 
these different compartments, a more detailed analysis of both the sources of tritium and variations in concentration are required. Temporal and spatial variations must be followed and trophic relationships need additional study. Although little concentration of tritium by either terrestrial or aquatic biota has been demonstrated and there exists little evidence to indicate that biomagnification of tritium occurs, release of larger quantities of tritium to the environment justifies additional research.

In general, the biological consequences of low-level irradiation have become an important consideration in all environments. State-of-the-art knowledge, as it would relate to tritium or other common radionuclides, is concerned mainly with somatic effects. Relatively few studies have been conducted on potential genetic effects, particularly under conditions of chronic exposure. When considering the environment, the primary concern is with populations. More sensitive parameters of radiation effects on individuals, populations, and communities need to be developed. Longer term or chronic studies should consider factors such as rates of growth, morphological abnomalities, onset of maturity, and reproductive capacity. Chromosomal investigations under both laboratory and field conditions should be extended, and the somatic and genetic consequences of such changes on populations, communities, and ecosystems should be evaluated.

Additional studies should be established under rigorously controlled experimental conditions to establish the effects of low-level chronic irradiation on the developing embryo. The effects of other environmental stress factors such as temperature, oxygen, other pollutants, and disease need to be studied and expanded to include the interaction of these factors with radiation effects.

Further studies of environmental conversion of tritium to tritium oxide are needed. The extent should be established to which the original source term consists of tritium oxide and the degree to which it remains as elemental tritium. Because of uncertainties in this area, it has been common radiological protection practice to assume that any measured tritium is tritium oxide. This places a severe and unnecessary restriction on exposure limits, if the exposure can be proved to be tritium gas.

Other experimental deficiencies lie in our lack of understanding of the basic relationships between very low-level, low-dose-rate, radiation exposure, and health effects in the living organism. Properly designed large scale, multigeneration, tritium exposure studies in experimental animals could add to our present knowledge of these basic relationships, and would be reassuring in view of the exposure of world populations that will result from tritium release.

Primary emphasis should be placed on definition of source terms and the oxidation rate of tritium in the environment. Secondary emphasis should be placed on tritium biological effects. 


\subsection{BIBL IOGRAPHY}

1) A. Nir. On the Interpretation of Tritium "Age" Measurements of Groundwater, J. Geophys. Res. 69:2589-2595, 1964.

2) D. G. Jacobs, Sources of Tritium and Its Behavior upon Release to the Environment, AEC Critical Review Series, TID-24635. U.S. Atomic Energy Conmission, Division of Technical Information, $90 \mathrm{p}, 1968$.

3) E. Eriksson, "An Account of the Major Pulses of Tritium and Their Effects in the Atmosphere," Tellus, 17(1):118-130, 1965.

4) J. J. Koranda, J. R. Martin and L. R. Anspaugh, The Significance of Tritium Releases to the Environment, Lawrence Radiation Laboratory, Livermore Rept. UCRL 73546, 1971.

5) P. B. Rhinehammer and P. H. Lamberger, eds., "Tritium Control Technology," Monsanto Research Corporation, Mound Laboratory, Miamisburg, OH, WASH-1269, Dec 1973.

6) G. N. Smith, R. J. Emerson, L. A. Temple and T. W. Galbraith, The 0xidation of Molecular Tritium in Mamma 1s, Arch. Biochem. Biophys. 46:22-30, 1953.

7) E. A. Pinson and W. H. Langham, Physiology and Toxicology of Tritium in Man, J. Appl. Physiol. 10:108-126, 1957.

8) C. W. DeLong, R. C. Thompson and H. A. Kornberg, Permeability of Excised Mouse, Rat, and Human Skin to Gaseous Tritium, Radiation Res. 1:214-217, 1954.

9) J. D. Eakins and W. P. Hutchinson, The Radiological Hazard from the Conversion of Tritium to Tritiated Water in Air by Metal Catalysts, Tritium, A. A. Moghissi and M. W. Carters, eds., Messenger Press, Las Vegas, pp. 392-399, 1973.

10) P. Joergensen and I. Rosenquist, Replacement and Bonding Conditions for A7ka $\mathrm{i}$ Ions and Hydrogen in Dioctahedral and Trioctahedral Micas, Norsk. Geol. Tidsokr., 43:497-536, 1963.

11) J. J. Koranda, "Preliminary Studies of the Persistence of Tritium and ${ }^{14} \mathrm{C}$ in the Pacific Proving Ground." Health Physics 11:11445-1457, 1965.

12) F. S. Nakayama and R. D. Jackson, "Diffusion of Tritiated Water in Soils," Soil Sci. Soc. Amer. Proc., 27(3):255-258, 1963.

13) E. Gorham and R. H. Hofstetter, Penetration of Peat Bogs and Lake Sediments by Tritium from Atmospheric Fallout, Ecology 52(5):898-902, 1971.

14) C. F. Jordan, J. R. Kl ine and D. S. Sasscer, Tritium Movement in an 01d Field Ecosystem Determined Experimentally, Proc. Third National Symposium on Radioecology, Oak Ridge, TN, pp. 199-203, May 10-12, 1971 .

15) J. J. Koranda, J. R. Martin and R. W. Wikkerink, Biological Half-Life Studies of Tritium in Animals with a Chronic Exposure at Sedan Crater, Lawrence Radiation Laboratory, Livermore Rept. UCRL-70914, 1969.

16) J. F. Cline, "Absorption and Metabolism of Tritium 0xide and Tritium Gas by Bean Plants," Plant Physiol. $28(4): 717-723,1953$.

17) F. Raney and Y. Vaadia, "Movement and Distribution of THO in Tissue Water and Vapor Transpired by Shoots of Hel ianthus and Nicotina," Plant Physiol. 40(1):378-382, 1965.

18) R. C. Thompson, "Studies of Metabolic Turnover with Tritium as a Tracer, I. Gross Studies on the Mouse," J. Biol. Chem., 197(1):87-87, 1952. 
19) R. C. Thompson, "Studies of Metabolic Turnover with Tritium as a Tracer, II. Gross Studies on the Rat," J. Biol. Chem., 200(2):737-743, 1953.

20) R. C. Thompson and J. E. Ballou, "Studies of Metabolic Turnover with Tritium as a Tracer, IV. Metabolically Inert Lipid and Prote in Fractions from the Rat," J. Biol. Chem., 208(2):883-888, 1954.

21) A. G. Evans, "New Dose Estimates from Chronic Tritium Exposures," Hea1th Physics 16:57, 1969.

22) A. A. Moghissi, R. Lieberman, M. W. Carter and J. E. Ragnier, "Biological Half-Life of Tritium," Health Physics, 21:57-60, 1971.

23) J. Barth, R. E. Stanley and A. A. Moghissi, "Biological Half-Life of Tritium in Goats," Health Physics 22(4):396, 1972.

24) G. D. Potter, G. M. Vattuone and D. R. McIntyre, "Metabolism of Tritiated Water in the Dairy Cow," Health Physics 22(44):405-409, 1972.

25) A. A. Moghissi, M. W. Carter and R. Lieberman, "Long-Term Evaluation of the Biological Half-Life of Tritium," Health Physics, 21:57-60, 1971.

26) A. A. Moghissi, M. W. Carter and E. W. Bretthauer, "Further Studies on the Long-Term Evaluation of the Biological Half-Life of Tritium," Health Physics 23:805-806, 1972.

27) D. Weinberger and J. W. Porter, Incorporation of Tritium 0xide into Growing Chlorella phrenoidose Cells, Science 117:636-638, 1953.

28) G. M. Rosenthal and M. L. Stewart, Tritium Incorporation in Algae and Transfer in Simple Aquatic Food Chains, Proc. Third National Symposium on Radioecology, Radionuclides in Ecosystems, 0ak Ridge, TN, pp. 440-444, May 10-12, 1971.

29) R. F. Foster, Tritium 0xide Absorption and Retention in the Body Water of Some Aquatic Organisms, HW35917, USAEC-GE Richland, WA, pp. 98-103, 1955.

30) M. L. Stewart, G. M. Rosenthal and J. R. Kl ine, Tritium: Discrimination and Concentration in Freshwater Microcosms, Proc. Third National Symposium on Radioecology, Radionuclides in Ecosystems, 0ak Ridge, TN, pp. 452-459, 1971.

31) J. A. Strand, W. L. Templeton and E. G. Tangen, Accumulation and Retention of Tritium (Tritiated Water) in Embryonic and Larval Fish, and Radiation Effect, Proc. Third National Symposium on Radioecology, Radionuclides in Ecosystems, Oak Ridge, TN, pp. 445-451, May 10-12, 1971 .

32) F. L. Harrison and J. J. Koranda, Tritiation of Aquatic Animals in an Experimental Freshwater Pool, Proc. Third National Symposium on Radioecology, Radionuclides in Ecosystems, Oak Ridge, TN, pp. 425-434, May 10-12, 1971 .

33) J. A. Strand, W. L. Templeton and E. G. Tangen, "Fixation and Long-Term Accumulation of Tritium in an Experimental Aquatic Environment," Pacific Northwest Laboratory, Annual Report for 1971, BNWL-1650, Vol 1. - Life Sciences, Part 2 - Ecological Sciences, $1.13-1.14,1972$.

34) R. Van Hook and S. L. Deal, "Tritium Uptake and El imination by Tissue-Bound and BodyWater Components in Crickets (Acheta domestions),") J. Insect. Physiol. 19:681-687, 1973.

35) International Commission on Radiological Protection, Report of Committee II on Permissible Dose for Internal Radiation, Oxford, Pergamon Press, 1959. 
36) W. S. Snyder, B. R. Fish, S. R. Berhard, Mary R. Ford and J. R. Muir, "Urinary Excretion of Tritium Following Exposure of Man to HTO- a Two Exponential Model," Phys. Med. Biol. 13:547-559, 1968.

37) J. W. Croach, "Theoretical Radiation Dose to the Human System from Assimilated Tritium," Health Phys. 24:17-22, 1973.

38) M. I. Balonov, E. I. Dolgirev and I. A. Likhtarev, "Exchange Kinetics and Dosimetry of Tritium Oxide in Man for Different Routes of Administration," Health Phys. 27:367-375, 1974.

39) J. W. Laskey, J. L. Parrish, and D. F. Cahill, "Some Effects of Lifetime Parental Exposure to Low Levels of Tritium on the F2 Generation," Radiat. Res. 56:171-179, 1973.

40) R. L. Dobson and M. F. Cooper, "Tritium Toxicity: Effect of Low-Level 3HOH Exposure on Developing Female Germ Cells in the Mouse," Radiat. Res. 58:91-100, 1974.

41) J. A. Strand, M. P. Fujihara, W. L. Templeton, and E. G. Tangen, "Suppression of Chondrococcus columnaris Immune Response in Ra inbow Trout Sublethally Exposed to Tritiated Water during Embryogenesis," Symp. on Radioactive Contamination of the Marine Environment. International Atomic Energy Agency, Vienna, Austria. pp. 543-550, 1973.

42) J. A. Strand, "Suppression of the Primary Immune Response in Rainbow Trout, Salmo gairdneri, Sublethally Exposed to Tritiated Water during Embryogenesis, "Ph.D. Dissertation, University of Washington, 137 pp. 1975.

43) Office of Radiation Programs, USEPA, "Tritium in Surface Waters," Rad. Data and Reports, 15:12, 1974.

44) L. E. Feinendegen, Tritium-Labeled Molecules in Biology and Medicine, Academic Press, New York, 1967.

45) L. E. Feinendegen and V. P. Bond, "Transmutation versus Beta Irradiation in the Pathological Effects of Tritium Decay," Tritium, A. A. Moghissi and M. W. Carter, eds., Messenger Press, Las Vegas, pp. 221-231, 1973.

46) R. B. Cumming, W. L. Russel1, and G. A. Sega, "Tritium-Induced Specific-Locus Mutations and Radiation Dose in the Male Mouse from Injected Tritiated Water, "Biology Division Annual Progress Report for Period Ending June 30, 1974, Oak Ridge Nat ional Laboratory, ORNL 4993, pp. 128-129, 1974.

47) E. P. Radford, "Statement of Concern," Environment 11:18-27, 1969.

48) R. V. Osborne, "Permissible Levels of Tritium in Man and the Environment," Radiation Res. 50:197-21], 1972 .

49) R. E. Weston, "Kinetic and Equilibrium Isotope Effects of Tritium Substitution," Tritium, A. A. Moghissi and M. W. Carter, eds., Messenger Press, Las Vegas, pp. 289-303, 1973.

50) Y. M. Shtukkenberg, "Physical Properties of Isotopes of Hydrogen," Tritium Oxide, Y. I. Moskalev, ed., Moscow, Atomizdat, translated as AEC-tr-7298, pp. 6-20, 1968.

51) R. F. Glasscock and W. G. Duncombe, "Differential Fractionation of Hydrogen Isotopes in Liver and Mammary Gland," Biochem. J. 58:440-447, 1954.

52) International Commission on Radiological Protection, "Progress Report from ICRP," Health Phys. 17:389, 1969. 
53) H. L. Crespi, M. L. Stewart, J. R. Kline, and J. J. Katz, "Discrimination Against Tritium by Fu11y Deuterated A1gae," Hea1th Phys. 23:111-112, 1972.

54) National Council on Radiation Protection and Measurements, Basic Radiation Protection Criteria, Report No. 39, 1971.

55) H. A. Johnson, "The Quality Factor for Tritium Radiation," Tritium, A. A. Moghissi and M. W. Carter, eds., Messenger Press. Las Vegas, pp. 231-239, 1973.

56) Y. I. Moskalev, V. F. Zhuravlev, A. G. Istomina, I. K. Petrovich and D. A. Kazbekova, "Relative Biological Ef́fectiveness of Tritium," Tritium, A. A. Moghissi and M. W. Carter, eds., Messenger Press, Las Vegas, pp. 24ז,-244, $1 \overline{973 .}$

57) R. L. Dobson, J. H. Arrington and T. C. Kwan, "Tritium Toxicity: Increased Relative Biological Effectiveness of $3 \mathrm{HOH}$ with Protraction of Exposure," Doc. UCRL-76558, 20 p., 1975.

58) A. M. Kellerer and H. H. Rossi, "RBE and the Primary Mechan ism of Radiation Action," Radiat. Res. 47:15-34, 1971.

59) W. H. Ellett and L. A. Braby, "The Microdosimetry of $250 \mathrm{kVp}$ and $65 \mathrm{kVp} \mathrm{X}$ Rays, 60Co Gamma Rays, and Tritium Beta Particles, Radiat. Res. 51:229-243, 1972.

60) E. J. Hall, R. Oliver and J. S. Bedford, "The Relative Biological Effectiveness of Tritium Beta Particles Compared to Gamma Radiation - Its Dependence on Dose Rate, Brit. J. Radiol. 40:704-710, 1967. 
A. A. Churm

ERDA Chicago Patent

Group

9800 S. Cass Avenue

Argonne, IL 60439

J. W. Beal

ERDA Div. of Magnetic

Fusion Energy

Washington, DC 20545

S. 0. Dean

ERDA Div. of Magnetic Fusion Energy

Washington, DC 20545

E. E. Kintner

ERDA Div. of Magnetic

Fusion Energy

Washington, DC 20545

J. M. Williams

ERDA Div. of Magnetic Fusion Energy

Washington, DC 20545

J. N. Grace

ERDA Div. of Magnetic

Fusion Energy

Washington, DC 20545

J. Baublitz

ERDA Div. of Magnetic

Fusion Energy

Washington, DC 20545

3 F. E. Coffman

ERDA Div. of Magnetic

Fusion Energy

Washington, DC 20545

J. F. Decker

ERDA Div. of Magnetic

Fusion Energy

Washington, DC 20545

3 K. M. Zwilsky

ERDA Div. of Magnetic

Fusion Energy

Washington, DC 20545

Dr. Philip M. Stone

ERDA Applied Plasma Physics

Program

Washington, DC 20545

G. W. Kuswa

ERDA Div. of Laser Fusion

Washington, DC 20545
R. Blaunstein

ERDA Div. of Biomedical

and Environmental Research

Washington, DC 20545

H. M. Busey

ERDA Div. of Military

Application

Washington, DC 20545

M. A. Bell

ERDA Div. of Safety

Standards and Compliance

Washington, DC 20545

27 ERDA Technical Information Center

M. S. Kaminsky

Argonne National Laboratory

9700 S. Cass Avenue

Argonne, IL 60439

V. A. Maroni

Argonne National Laboratory

9700 S. Cass Avenue

Argonne, IL 60439

P. M. Persiani

Argonne National Laboratory

9700 S. Cass Avenue

Argonne, IL 60439

M. Petrick

Engineering and Technology Division

Argonne National Laboratory

9700 S. Cass Avenue

Argonne, IL 60439

W. E. Parkins, Manager

Atomics International

Component Engineering and

Technology Division

North American Rockwell

P. O. Box 309

Canoga Park, CA 91304

D. Gurinsky

Brookhaven National Laboratory

ERDA Brookhaven Area Office

Upton, NY 11973

\section{H. J. Kouts}

Brookhaven National Laboratory ERDA Brookhaven Area Office

Upton, NY 11973

S. Pearlstein

Brookhaven National Laboratory ERDA Brookhaven Area Office

Upton, NY 11973
OFFSITE

J. R. Powell

Brookhaven National Laboratory ERDA Brookhaven Area Office

Upton, NY 11973

A. J. Impink, Jr.

Carnegie Melion University

Pittsburgh, PA 15213

R. A. Gross

Plasma Research Laboratory

236 SW Mudd Bldg.

Col umbia University

New York, NY 10027

W. C. Gough

Electric Power Research Inst.

3412 Hillview Ave.

Palo Alto, CA 94304

G. R. Hopkins

Gulf General Atomic

P.0. Box 1111

San Diego, CA 92112

Zeinab Sabri

Iowa State University

261 Sweeney Hali

Nuclear Engineering Department Ames, IA 50010

R. Borg

Lawrence Livermore Laboratory

P.0. Box 808

Livermore, CA 94550

T. K. Fowler

Lawrence Livermore Laboratory

P.0. Box 808

Livermore, CA 94550

R. Moir

Lawrence Livermore Laboratory

P.0. Box 808

Livermore, CA 94550

A. Carl Haussmann

Lawrence Livermore Laboratory

P.0. Box 808

Livermore, CA 94550

J. Hovingh

Lawrence Livermore Laboratory

P.0. Box 808

Livermore, CA 94550

R. F. Post

Lawrence Livermore Laboratory

P.0. Box 808

Livermore, CA 94550

C. J. Tayior

Lawrence Livermore Laboratory

P.0. Box 808

Livermore, CA 94550 
R. Werner

Lawrence Livermore

Laboratory

P.0. Box 808

Livermore, CA 94550

L. L. Wood

Lawrence Livermore

Laboratory

P.0. Box 808

Livermore, CA 94550

W. Bauer

Division Supervisor

of Physical Research

Sandia Labs Livermore

Livermore, CA 94550

L. Booth

Los Alamos Scientific

Laboratory

CTN Research

P.0. Box 1663

Los Alamos, NM 87544

D. J. Dudziak

Los Alamos Scientific

Laboratory

CTN Research

P.0. Box 1663

Los Alamos, NM 87544

D. B. Henderson

Los Alamos Scientific Laboratory

CTN Research

P.0. Box 1663

Los Alamos, NM 87544

E. L. Kemp

Los Alamos Scientific

Laboratory

CTN Research

P.0. Box 1663

Los Alamos, NM 87544

F. L. Ribe

Los Alamos Scientific

Laboratory

CTN Research

P.0. Box 1663

Los Alamos, NM 87544

L. Stewart

Los Alamos Scientific

Ladoratory

CTN Research

P.0. Box 1663

Los Alamos, NM 87544

K. Thomassen

Los Alamos Scientific Laboratory

CTN Research

P.0. Box 1663

Los Alamos, NM 87544
0. K. Harling

Massachusetts Institute of

Technology

Cambridge, MA 02139

Bruno Coppi

Department of Physics

Massachusetts institute of

Technology

Cambridge, MA 02139

L. Lidsky

Dept. of Nuclear Engineering

Massachusetts Institute of

Technology

Cambridge, MA 02139

Norm Rasmussen

Dept. of Nuclear Engineering

Massachusetts Institute of

Technology

Cambridge, MA 02139

David Rose

Massachusetts Institute of

Technology

Cambridge, MA 02139

R. E. Stickney

Mechanical Engineering

Massachusetts Institute of

Technology

Cambridge, MA 02139

J. J. Reinmann

NASA - Lewis Research Center

2100 Bookpark Rd.

Cleveland, $\mathrm{OH} 44135$

Vincent Arp

National Bureau of Standards

Cryogenics Division

Boulder, CO 80302

J. F. Clarke

Oak Ridge National

Laboratory

P.0. Box $Y$

Oak Ridge, TN 37830

A. P. Fraas

Oak Ridge National

Laboratory

P.0. Box Y

Oak Ridge, TN 37830

J. Rand McNaliy, Jr.

Oak Ridge National

Laboratory

P.0. Box Y

Oak Ridge, TN 37830

D. Steiner

Oak Ridge National

Laboratory

P.0. Box Y

Oak Ridge, TN 37830
J. Scott

Oak Ridge National Laboratory

P. 0. Box $X$

Oak Ridge, TN 37830

J. Banford

Physics Internationa?

2700 Merced St.

San Leandro, CA 94577

R. A. Huse

Public Service Electric

and Gas Co.

80 Park Place

Newark, NJ 07101

M. Gottlieb

Princeton University, PPPL

P.0. Box 451

Princeton, NJ 08540

R. G. Mills

Princeton University

P.0. Box 45]

Princeton, NJ 08540

E. C. Tanner

Princeton University

P.0. Box 451

Princeton, NJ 08540

H. Perkins

Dept. of Chemistry

Princeton University

Princeton, NJ 06540

R. E. Gold

303 Sayre Hall

Forrestal Campus

P.0. Box 451

Princeton, NJ 06540

M. Kristiansen

Texas Tech. University

Lubbock, TX 79409

A. F. Haught

United Aircraft Research Lab. United Aircraft Corporation

East Hartford, CT 06108

L. Levine

U.S. Naval Research Laboratory

Washington, DC 20390

C. Z. Serpan, Jr.

U.S. Naval Research Laboratory

Washington, DC 20390

Francis Chen

University of California

Electronics Research

Laboratory

College of Engineering

Berkeley, CA 94720 
A. J. Lichtenberg University of California Electronics Research Laboratory

College of Engineering Berkeley, CA 94720

Dave Okrent

U.C.L.A.

Los Angeles, CA 90024

C. D. Hendricks University of Illinois Nuclear Engineering

Laboratory

Urbana, IL 61801

G. H. Miley University of Illinois Nuclear Engineering Laboratory

Urbana, IL 61801

Terry Kammash University of Michigan Nuclear Engineering Department

Ann Arbor, MI 48105

Dean Abrahamson University of Minnesota School of Public Affairs

Social Science

Building/309

Minneapolis, MN 55455

W. G. Davey

University of Texas

Department of Physics

Austin, TX 78712

E. Linn Draper, Jr. University of Texas Department of Physics Austin, TX 78712

W. E. Drummond University of Texas Department of Physics Austin, TX 78712

Abraham Hertzberg University of Washington Aerospace Research Laboratory 316 Guggenheim Seattle, WA 98105

A. L. Babb

University of Washington Nuclear Engineering Department

Seattle, WA 98105
R. Conn

University of Wisconsin

Nuclear Engineering

Department

Madison, WI 53706

G. L. Kulcinski

University of Wisconsin

Nuclear Engineering

Department

Madison, WI 53706

C. W. Maynard

University of Wisconsin

Nuclear Engineering

Department

Madison, WI 53706

D. Lichtman

Department of Physics

University of Wisconsin

Milwaukee, WE 53201

E. E. Donaldson

Washington State University

Deparment of Physics

Pullman. WA 99163

D. D. Mahlum

Division of Biomedical

and Environmental Research

Washington, DC 20545

J. V. Vanston

Engineering Science

Building

University of Texas

Austin, TX 78712

Leslie S. Ramsey

450 North 5 th Street

Indiana, PA 15701 
ONSITE

ERDA Richland Operations Office

W. A. Burns

Atlantic Richfield Hanford Company

J. D. Kaser

Hanford Engineering

Development Labs

D. G. Doran

H. H. Yoshikawa

\section{Battelle-Northwest}

D. T. Aase

G. S. Allison

T. W. Ambrose

D. G. Atteridge

D. A. Baker

J. L. Bates

M. A. Bayne

E. R. Bradley

J. L. Brimhall

R. L. Brodzinski

R. J. Brouns

L. R. Bunnell

L. L. Burger

S. H. Bush

N. E. Carter

T. D. Chikalla

R. G. Clark

T. L. Criswell

S. D. Dahlgren

M. T. Dana

D. E. Deonigi

R. L. Dillon

D. A. Dingee

P. J. Dionne

B. H. Duarie

J. W. Finnigan

J. C. Fox

J. J. Fuquay

J. E. Garnier

R. D. Gastil

B. F. Gore

J. N. Hartley

A. J. Haverfield

U. P. Jenquin

A. B. Johnson, Jr.

R. H. Jones

T. J. Kabele

W. S. Kelly

H. E. Kissinger

J. A. Kottwitz

N. Laegried

B. R. Leonard, Jr

D. L. Lessor

H. B. Liemohn

R. C. Liikala

M. A. McKinnon

R. F. Maness

R. P. Marshall
ONSITE

Battelle-Northwest - Continued

E. S. Murphy

R. D. Nelson

D. F. Newman

R. E. Nightingale

D. E. Olesen

L. T. Pedersen

R. T. Perry

D. R. Pratt

L. A. Rancitelli

J. F. Remark

U. S. Renné

R. E. Rhoads

W. O. Richmond

W. F. Sandusky

L. C. Schmid

N. M. Sherer

E. P. Simonen

R. I. Smith

J. K. Soldat

C. W. Stewart

K. B. Stewart

R. W. Stewart

10 J. A. Strand

D. L. Styris

A. M. Sutey

V. L. Teofilo

G. L. Tingey

M. T. Thomas

10 R. C. Thompson

L. H. Toburen

T. J. Trapp

R. Wang

R. E. Westerman

L. D. Williams

10 J. R. Young M. G. Zimerman

1 Technical Publications (BH)

5 Technical Information 